\title{
Effects of the Dietary Supplementation with a Microalga Extract on Broiler Performance and Fatty-Acid Meat Profile
}

Original Article

\section{EAuthor(s)}

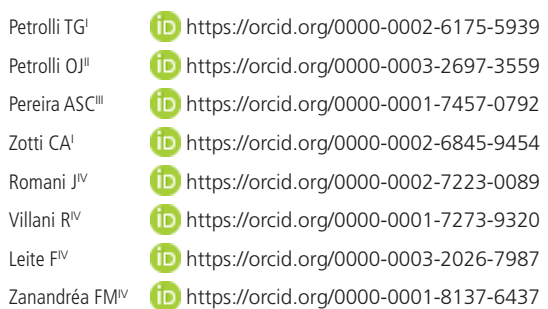

Professor on Post-Graduate program in Anima health and Production - Universidade do Oeste de Santa Catarina - Xanxerê, SC, Brazil

Universidade do Oeste de Santa Catarina Xanxerê, SC, Brazil.

III Faculty of Animal Science and Food Engineering - Universidade de São Paulo - Pirassununga, SP Brazil

iv Graduate student - Universidade do Oeste de Santa Catarina - Xanxerê, SC, Brazil.

\section{Mail Address}

Corresponding author e-mail address Tiago Goulart Petrolli

Rua Dirceu Giordani, 696 - Bairro Jardim Tarumã - CEP 89820-000 - Xanxerê, SC, Brazil.

Phone: 5549 3441-7000

Email: tiago.petrolli@unoesc.edu.br

\section{-Keywords}

Docosahexaenoic acid, poultry, nutrition, meat quality.

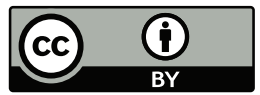

Submitted: 03/December/2018 Approved: 02/May/2019

\section{ABSTRACT}

The present study was carried out in the poultry sector of UNOESC Xanxerê to evaluate the effect of various inclusion levels of seaweed (Schizotrichium ssp.) in the diet of broiler chickens in terms of performance, carcass yield, organ profiles and fatty acids levels in meat. We studied 480 one-day-old Cobb chicks, distributed in a completely randomized experimental design, with four treatments and six replicates containing 20 birds each, totaling 24 experimental units. At 7, 21 and 35 days of age, the birds were weighed for performance evaluation (live weight, weight gain, feed intake, feed conversion and mortality). At 35 days of age, one chicken per experimental unit was sacrificed for evaluation of carcass yield and its parts, together with isolation of the left thigh for analysis of the fatty acid profile. The inclusion of seaweed in the diet did not alter the characteristics of performance or yield in carcass and organs; however, the supplement changed the profile of fatty acids of the meat, enriching the omega-3 series, primarily DHA. We conclude that marine algae of the genus Schizotrichium can be added to rations without compromising the development of the birds to improve the profile of fatty acids in the meat.

\section{INTRODUCTION}

Several health benefits related to the frequent intake of omega-3 fatty acids by humans have been described in the literature, and fatty acids with carbon chains longer than 20 carbons provide the most contributions. Omega-3 fatty acids exert positive effects on the immune system, as well as on conditions such as arrhythmia, coronary disease, inflammation and diabetes, and breast, prostate and colon cancer (Ao et al., 2015). They also contribute for the prevention of atherosclerosis and reduce the progression of cardiovascular problems (Cherian et al., 2007), and play important roles during gestation and early childhood development (Ao et al., 2015). Omega-3 fatty acids include the eicosapentaenoic (EPA, 20:5 n-3) and docosahexaenoic acids (DHA, 22:6n-3).

Promising alternative high-quality sources of omega- 3 fatty acids are products that manipulate the lipid profiles of meat, with potential to add value to meat; these products are considered nutraceuticals. The most common products used to enrich animal meat with omega-3 fatty acids are based on seeds and linseed oil. However, these are not commonly available because of their production seasonality and associated high costs. Linseed oil is effective to enrich poultry meats with linolenic acid (18:3, n-3) (Shunthwal \& Sheoran, 2017), but it does not increase eicosapentaenoic acid (EPA) or docosahexaenoic acid (DHA) meat levels, because poultry have a limited capacity of endogenous metabolic conversion of linolenic acid into EPA and DHA (Hargis \& Van Elswyk, 1993). 
Petrolli TG, Petrolli OJ, Pereira ASC, Zanandréa FM Zotti CA, Romani J, Villani R, Leite F,

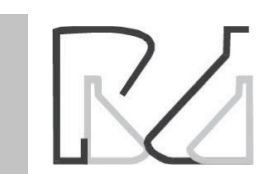

Recently, seaweed production has been developed in industrial-scale for animal feeding, as a potential feed source to enrich broiler meat with polyunsaturated fatty acids (PUFA). Microalgae of the genus Schizotrichium contain high DHA levels (Zeller et al., 2001; Barclay et al. 1994), which is the fatty acid of the omega-3 series with the highest number of unsaturated bonds, and therefore, has a high potential as a feed additive for meat enrichment.

There are several literature articles on the enrichment of eggs with omega-3 fatty acids. For instance, Cherian et al. (2007) described that the inclusion of fish oil in layer feeds effectively enriched eggs with PUFA. Similarly, Herber \& van Elswyk (1996) found an increase in DHA levels in the eggs of layers fed marine microalga extracts. However, few studies (Yan et al., 20130) were carried out on the enrichment of chicken meat with omega-3 from algae sources.

Therefore, the objective of this study was to evaluate the effects of feeding broilers with extracts of marine microalgae of the genus Schizotrichium on performance in terms of carcass yield, cuts, organs and fatty acid profiles (DHA) in the meat of broiler chickens.

\section{MATERIALSAND METHODS}

\section{Poultry, diets and housing}

The study was carried out at the poultry sector, UNOESC Xanxerê, state of Santa Catarina, Brazil. In total, 480 Cobb females were reared from 1 to 35 days of age. Birds were distributed in a completely randomized experimental design, consisting of four treatments (Table 1) with six replicates of 20 birds each.

Table 1 - Treatments.

\begin{tabular}{ll}
\hline Treatment & Addition of microalgae \\
\hline T1 & Control $(0 \%)$ \\
T2 & 5 gmicroalga extract $/ \mathrm{kg}$ feed $(0.5 \%)$ \\
T3 & 10 microalga extract $/ \mathrm{kg}$ feed $(1.0 \%)$ \\
T4 & 20 microalga extract $/ \mathrm{kg}$ feed $(2.0 \%)$ \\
\hline
\end{tabular}

At one day of age, chicks were housed in 2-m2 experimental pens per replicate, covered with fresh wood-shavings litter and equipped with nipple drinkers and a tube feeder. Feed and water were provided ad libitum throughout the experimental period. The experimental diets were formulated to contain equal metabolizable energy and crude protein levels, using the nutritional requirements and feedstuff composition proposed by Rostagno et al. (2017).
Effects of the Dietary Supplementation with a Microalga Extract on Broiler Performance and FattyAcid Meat Profile

The commercial microalga extract product (All-G Rich, Alltech, Brazil) included in the feeds derives from Schizochitrium limacinum, and contains 50\% ether extract and $17 \%$ DHA. The fatty acid profile of the product, according to the manufacturer, is shown in Table 4.

Table 2 - Ingredients and calculated nutritional composition of the starter feed (1 to 21 days).

\begin{tabular}{lcccc}
\hline & \multicolumn{4}{c}{ Microalga extract inclusion rate } \\
\hline Ingredients & $0 \%$ & $0.5 \%$ & $1 \%$ & $2 \%$ \\
\hline Corn, g/kg & 544 & 540.6 & 537.3 & 530.6 \\
\hline Soybean meal(46\%), g/kg & 361.65 & 360.0 & 358.3 & 355.0 \\
\hline Soybean oil, g/kg & 27.79 & 27.77 & 27.6 & 27.4 \\
\hline Dicalcium phosphate, g/kg & 18.3 & 18.3 & 18.3 & 18.3 \\
\hline Microalga extract, g/kg & - & 5 & 10 & 20 \\
\hline Limestone, g/kg & 8.25 & 8.25 & 8.15 & 8.06 \\
\hline Salt, g/kg & 3.25 & 3.25 & 3.25 & 3.25 \\
\hline DL-Methionine (99\%), g/kg & 2.6 & 2.6 & 2.7 & 2.7 \\
\hline L-Lysine HCl, g/kg & 2.25 & 2.30 & 2.40 & 2.50 \\
\hline Choline chloride(60\%), g/kg & 1.0 & 1.0 & 1.0 & 1.0 \\
\hline Vitamin supplement1, g/kg & 15 & 15 & 15 & 15 \\
\hline Mineral supplement2, g/kg & 15 & 15 & 15 & 15 \\
\hline Antioxidant3, g/kg & 1.0 & 1.0 & 1.0 & 1.0 \\
\hline Calculated nutritional values & & & & \\
\hline Metabolizable energy, kcal/kg & 2950 & 2950 & 2950 & 2950 \\
\hline Crude protein, g/kg & 215.00 & 215.00 & 215.00 & 215.00 \\
\hline Digestible lysine, g/kg & 12.00 & 12.00 & 12.00 & 12.00 \\
\hline Digestible methionine, g/kg & 5.44 & 5.44 & 5.44 & 5.44 \\
\hline Digestible Met. + Cys., g/kg & 8.39 & 8.39 & 8.39 & 8.39 \\
\hline Digestible threonine, g/kg & 7.55 & 7.55 & 7.55 & 7.55 \\
\hline Digestible tryptophan, g/kg & 2.46 & 2.46 & 2.46 & 2.46 \\
\hline Digestible arginine, g/kg & 14.14 & 14.14 & 14.14 & 14.14 \\
\hline Digestible valine, g/kg & 9.25 & 9.25 & 9.25 & 9.25 \\
\hline Calcium, g/kg & 9.02 & 9.02 & 9.02 & 9.02 \\
\hline Available phosphorus, g/kg & 4.51 & 4.51 & 4.51 & 4.51 \\
\hline Sodium, g/kg & 1.70 & 1.70 & 1.70 & 1.70 \\
\hline Potassium, g/kg & 8.49 & 8.49 & 8.49 & 8.49 \\
\hline Chline, g/kg & 3.77 & 3.77 & 3.77 & 3.77 \\
\hline
\end{tabular}

Vitamin supplement contains per $\mathrm{kg}$ of product: Vit. A - 10,000,000 IU; Vit. D3 2,000,000 IU; Vit. E - 30,000 IU; Vit. B1 - 2.0g; Vit. B2 - 6.0g; Vit. B6 - 4.0g; Vit. B12 - 0.015g; Pantothenic acid- 12.0g; Biotin - 0.1g; Vit. K3 - 3.0g; Folic acid- 1.0g; Nicotinic acid - 50.0g; Selenium- 250.0mg; and vehicle q.s. $1000 \mathrm{~g}$;

${ }^{2}$ Mineral supplement contains per kg of product: Iron - 100.0g; Cobalt - 2.0g; Copper - 20.0g; Manganese - 160.0g; Zinc - 100.0g; lodine - 2.0g; and vehicle q.s.p. 1000g; ${ }^{3}$ Butyl hydroxy toluene $99 \%$. 
Petrolli TG, Petrolli OJ, Pereira ASC, Zotti CA, Romani J, Villani R, Leite $F_{\text {, }}$ Zanandréa FM

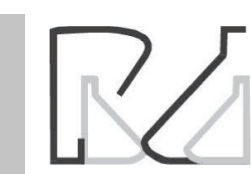

Table 3 - Ingredients and calculated nutritional composition of the grower feed (22 to 35 days).

\begin{tabular}{lcccc}
\hline & \multicolumn{4}{c}{ Microalga extract inclusion rate } \\
\hline Ingredient & $0 \%$ & $0.5 \%$ & $1 \%$ & $2 \%$ \\
\hline Corn, g/kg & 578.66 & 575.32 & 572.00 & 565.33 \\
\hline Soybean meal (46\%), g/kg & 309 & 307.35 & 305.70 & 302.40 \\
Soybean oil, g/kg & 44.89 & 44.80 & 44.70 & 44.51 \\
\hline Dicalcium phosphate, g/kg & 18.64 & 18.68 & 18.71 & 18.77 \\
\hline Microalga extract, g/kg & - & 5 & 10 & 20 \\
\hline Limestone, g/kg & 8.41 & 8.37 & 8.32 & 8.22 \\
\hline Salt, g/kg & 3.32 & 3.32 & 3.32 & 3.32 \\
\hline DL-Methionine (99\%), g/kg & 3.11 & 3.14 & 3.17 & 3.23 \\
\hline L-Lysine HCl, g/kg & 1.94 & 2.01 & 2.07 & 2.20 \\
\hline Choline chloride(60\%), g/kg & 1.0 & 1.0 & 1.0 & 1.0 \\
\hline Vitamin supplement1, g/kg & 15.0 & 15.0 & 15.0 & 15.0 \\
\hline Mineral supplement2, g/kg & 15.0 & 15.0 & 15.0 & 15.0 \\
\hline Antioxidant3, g/kg & 1.0 & 1.0 & 1.0 & 1.0 \\
\hline & & & & \\
\hline
\end{tabular}

Calculated values

\begin{tabular}{lcccc}
\hline Metabolizable energy, kcal/kg & 3100 & 3100 & 3100 & 3100 \\
\hline Crude protein, g/kg & 194.00 & 194.00 & 194.00 & 194.00 \\
\hline Digestible lysine, g/kg & 10.50 & 10.50 & 10.50 & 10.50 \\
\hline Digestible methionine, g/kg & 5.05 & 5.05 & 5.05 & 5.05 \\
\hline Digestible Met. + Cys., g/kg & 7.75 & 7.75 & 7.75 & 7.75 \\
\hline Digestible threonine, g/kg & 6.84 & 6.84 & 6.84 & 6.84 \\
\hline Digestible tryptophan, g/kg & 2.13 & 2.13 & 2.13 & 2.13 \\
\hline Digestible arginine, g/kg & 12.27 & 12.27 & 12.27 & 12.27 \\
\hline Digestible valine, g/kg & 8.20 & 8.20 & 8.20 & 8.20 \\
\hline Calcium, g/kg & 8.24 & 8.24 & 8.24 & 8.24 \\
\hline Available phosphorus, g/kg & 4.10 & 4.10 & 4.10 & 4.10 \\
\hline Sodium, g/kg & 2.05 & 2.05 & 2.05 & 2.05 \\
\hline Potassium, g/kg & 7.46 & 7.46 & 7.46 & 7.46 \\
\hline Chlorine, g/kg & 3.56 & 3.56 & 3.56 & 3.56 \\
\hline
\end{tabular}

Vitamin supplement contains per kg of product: Vit. A - 10,000,000 IU; Vit. D3 2,000,000 IU; Vit. E - 30.000 IU; Vit. B1 - 2.0g; Vit. B2 - 6.0g; Vit. B6 - 4.0g; Vit. B12 - 0.015g; Pantothenic acid - 12.0g; Biotin - 0.1g; Vit. K3 - 3.0g; Folic acid-1.0g; Nicotinic acid- 50.0g; Selenium-250.0mg; and vehicle q.s.p. 1000g;

${ }^{2}$ Mineral supplement containing per $\mathrm{kg}$ of product: Iron $-100.0 \mathrm{~g}$; Cobalt $-2.0 \mathrm{~g}$; Copper - 20.0g; Manganese - 160.0g; Zinc - 100.0g; lodine - 2.0g; and vehicle q.s.p.- 1000g;

${ }^{3}$ Butyl hydroxy toluene $99 \%$.
Effects of the Dietary Supplementation with a Microalga Extract on Broiler Performance and FattyAcid Meat Profile

Table 4 - Fatty acid profile of the evaluated extract of the microalgae Schizotrichium limacinum 1.

\begin{tabular}{lcc}
\hline Fatty Acid Profile & C:D2 & g/100g of fat content \\
\hline Myristic acid & $14: 0$ & 3.86 \\
\hline Myristoleicacid & $14: 1$ & 1.60 \\
\hline Palmitic acid & $16: 0$ & 54.69 \\
\hline Palmitoleic acid & $16: 1$ & $<0.10$ \\
\hline Margaric acid & $17: 0$ & 0.63 \\
\hline Margaroleicacid & $17: 1$ & $<0.01$ \\
Stearic acid & $18: 0$ & 1.80 \\
Oleic acid & $18: 1$ & $<0.10$ \\
Linoleic acid & $18: 2$ & $<0.10$ \\
Linolenic acid & $18: 3$ & $<0.10$ \\
Arachidic acid & $20: 0$ & 0.28 \\
Arachidonic acid & $20: 4$ & $<0.10$ \\
Eicosapentaenoic acid & $20: 5$ & 0.28 \\
\hline Docosahexaenoic acid & $22: 6$ & 27.20 \\
\hline 'According to the manufacturer. & & \\
ELipid number, where C is the number of carbon atoms and D is the number of double \\
bonds.
\end{tabular}

Live performance, carcass and parts yields, and organ relative weights

Birds and feed residues were weighed on d 7, 21 and 35 to determine the live performance parameters body weight (BW), body weight gain (BWG), feed intake (FI), and feed conversion ratio (FCR).

At 35 days of age, one bird per replicate was sacrificed according to the guidelines of the Brazilian Council for the control of Animal Experimentation (CONCEA) for euthanasia (Brasil, 2013). Empty carcass yield, and parts (wing, leg, thigh and back), and organ (heart, liver, proventriculus, gizzard and small intestine) relative weights were calculated using the following equation:

$$
\text { Carcass }(\%)=\frac{\text { carcass weight }}{\text { body weight at slaughter }} \times 100
$$

Relative parts or organ $(\%)=\frac{\text { part or organ weight }}{\text { body weight at slaughter }} \times 100$

\section{Meat fatty acid profile}

The left thigh of one bird per replicate was collected unit, frozen at $-2^{\circ} \mathrm{C}$ and submitted to the Meat Science Laboratory of FMVZ/USP, Pirassununga, São Paulo, Brazil.

In the lab, a subsample weighing approximately 2.8 $\mathrm{g}$ was ground, homogenized, and placed in a $50-\mathrm{mL}$ Falcon tube. 
Petrolli TG, Petrolli OJ, Pereira ASC, Zotti CA, Romani J, Villani R, Leite F, Zanandréa FM
Effects of the Dietary Supplementation with a Microalga Extract on Broiler Performance and FattyAcid Meat Profile
Lipids were extracted according to the method of Folch et al. (1957). The sample was homogenized with a 2:1 solution of chloroform and methanol in a homogenizer (Ultra Turrax Marconi ${ }^{\circledR}$, Kirgizstan) A $1.5 \% \mathrm{NaCl}$ solution was added to the sample, which was then centrifuged at 2400rpm for $20 \mathrm{~min}$.

The separated fat was methylated and the methyl esters were formed as described by Kramer etal. (1997). Fatty acids were quantified by gas chromatography (CG-2010 Plus, Shimadzu, auto-injector AOC 20i, Japan), using a SP-2560 capillary column (100-m long $\times \quad 0.25-\mathrm{mm}$ diameterand0.02-mm thick, Supelco, Bellefonte, PA, USA). Initial temperature was $45^{\circ} \mathrm{C}$, with progressive heating to $175{ }^{\circ} \mathrm{C}$, and remaining for 27 minutes. Thereafter, further increase of $4{ }^{\circ} \mathrm{C} /$ min was initiated up to $215^{\circ} \mathrm{C}$, and remaining for 35 minutes. Hydrogen $\left(\mathrm{H}_{2}\right)$ was used as drag gas with flow of $40 \mathrm{~cm} 3 / \mathrm{s}$. Fatty acids were quantified by normalizing the methyl ester peak areas using the GS Software ver. 2.42. Fatty acids are expressed as percentages of total methyl ester quantified.

\section{Statistical analysis}

Data were subjected to linear and quadratic regression analysis, at $p<0.05$ significance, using statistical software R (2014).

\section{RESULTS AND DISCUSSION}

Body weight, BWG, FI and FCR measured in the periods of 1-7 days or 1-21 days were not influenced by the dietary inclusion of MAE ( $p>0.05$; Table5). However, from 1 to 35 days, MAE had a linear effect $(p=0.035)$ on BW and a quadratic effect $(p=0.037)$ on FCR, but did not affect BWG or FI. Studies evaluating the inclusion of microalgae in broiler diets (Rymer et al., 2010; Yan \& Kim, 2013) and laying hens (Neijat et al., 2016) did not find any influence on live performance, independently of the production phase. In addition, several authors (Ernest \& Warren, 1990; Ross \& Dominy, 1990; Ventura et al., 1994; Toyomizu et al., 2001; Rymer et al., 2010), when comparing different sources of omega- 3 fatty acids (fish oil and flaxseed oil) with seaweed biomass at different inclusion levels in the diet of broilers, did not find any performance differences, which suggests little influence of the addition of this ingredient on poultry performance.

The positive effect of MAE supplementation on BW and BWG during the total experimental period (1-35 d) found in the present study may be explained by the positive effect of DHA on the development of nervous tissue and in the early phase of body development. Padhi et al. (2003) found that algae may be included in layer diets at up to $7.5 \%$ inclusion level without any adverse effects on $\mathrm{FI}, \mathrm{FCR}$, body development, or egg quality.

Table 5 - Performance of broilers fed increasing levels of microalga extract.

\begin{tabular}{|c|c|c|c|c|c|c|c|}
\hline & \multicolumn{5}{|c|}{ Microalga dietary inclusion level } & \multicolumn{2}{|c|}{$p$-value } \\
\hline & Control & $0.5 \%$ & $1.0 \%$ & $2.0 \%$ & CV $(\%)$ & Linear & Quadratic \\
\hline \multicolumn{8}{|l|}{ BW (g) } \\
\hline $1-7 d$ & 166 & 166 & 169 & 173 & 7.24 & ns & ns \\
\hline $1-21 d$ & 696 & 722 & 713 & 740 & 5,76 & & \\
\hline $1-35 d$ & 1711 & 1800 & 1767 & 1783 & 2.56 & $0.037 *$ & ns \\
\hline \multicolumn{8}{|c|}{ BWG (g) } \\
\hline $1-7 d$ & 113 & 113 & 116 & 120 & 10.65 & ns & ns \\
\hline $1-21 d$ & 642 & 669 & 646 & 687 & 6.37 & ns & ns \\
\hline $1-35 d$ & 1657 & 1747 & 1703 & 1730 & 2.71 & ns & ns \\
\hline \multicolumn{8}{|l|}{$\mathrm{FI}(\mathrm{g})$} \\
\hline $1-7 d$ & 147 & 140 & 141 & 148 & 16.61 & ns & ns \\
\hline $1-21 d$ & 1008 & 1044 & 1001 & 1071 & 8.08 & ns & ns \\
\hline $1-35 d$ & 2698 & 2705 & 2445 & 2755 & 3.84 & ns & ns \\
\hline \multicolumn{8}{|l|}{ FCR } \\
\hline $1-7 d$ & 1.31 & 1.24 & 1.22 & 1.24 & 15.93 & ns & ns \\
\hline $1-21 d$ & 1.57 & 1.56 & 1.55 & 1.56 & 5.74 & ns & ns \\
\hline $1-35 d$ & 1.61 & 1.55 & 1.59 & 1.57 & 3.19 & ns & $0.035^{* *}$ \\
\hline
\end{tabular}

$\mathrm{CV}=$ Coefficient of variation; BW = body weight; BWG = body weight gain; FI = feed intake; $F C R=$ feed conversion ratio.

* Linear effect: $p=0.037 ; y=1734.96+25.12 x ; r 2=0.30$

${ }^{*}$ Quadratic effect: $P=0.035 ; y=1.619+0.024 x+0.002 \times 2 ; r 2=0.80$

The lower FCR obtained in birds fed MAE $(p<0.05)$ during the total experimental period (1-35 d) are in agreement with the findings of Tenório (2015), who demonstrated higher BWG and better FCR in broilers fed marine microalgae. The better performance of birds fed MAE may be attributed to an improvement of the immune system, as reported by Maroufyan et al. (2012), who observed that the dietary supply of $n-3$ fatty acid sources enhanced the immune response of broiler challenged with IBD (infectious bursal disease).

The increase in body weight could be explained by the positive effect of DHA on the development of nervous tissue in the early phase of body development; however, this was not measured in our research. Ao et al. (2015) asserted that DHA plays an essential role in the early development and enhancement of the immune system. As birds have limited capacity of endogenous conversion of linoleic acid into EPA and DHA (Hargis \& Van Elswyk, 1993), the dietary supplementation with sources of these fatty acids has a greater impact when compared to other species of zootechnical interest. On the other hand, Carrillo et al. (1990) observed a reduction in broiler growth as dietary 
Petrolli TG, Petrolli OJ, Pereira ASC, Zotti CA, Romani J, Villani R, Leite F, Zanandréa FM

\section{Effects of the Dietary Supplementation with a Microalga Extract on Broiler Performance and Fatty- Acid Meat Profile}

alga (Macrocystispyrifera) inclusion levels increased. Venkataraman et al. (1994) reported that the inclusion of $14 \%$ and $17 \%$ of algae (Spirulina platensis) in broiler diets in replacement of fishmeal did not affect their performance or meat quality, except for a more intense yellow color of the meat of birds supplemented with seaweed. Gu et al. (1988) concluded that the addition of $2 \%$ seaweed improved broiler performance and carcass yield. El-Deek et al. (1987) and El-Deek \& Brikaa (2009) found that the use of various levels of algae had no effect on carcass quality.

There was no influence $(p>0.05)$ of the dietary treatments on carcass yield and on parts (breast, leg, thigh, back, and wings) relative weights (Table 6). These results are in agreement with those of Abudabos et al. (2013), who did not detect any differences in carcass yield among broilers fed different seaweed, and with Tenório (2015), who evaluated increasing dietary seaweed levels in broilers diets and did not find any carcass and breast yield differences, despite significantly higher leg yield and abdominal fat deposition. The data obtained in the present study suggest that the fatty acid profile of the diets containing MAE had no influence on carcass and parts yields, and did not interfere with levels of fat or other nutrients in each carcass component.

Table 6 - Carcass yield and relative weight (\%) of carcass parts and organs of broilers fed increasing microalga extract levels from 1 to 35 days of age.

\begin{tabular}{|c|c|c|c|c|c|c|}
\hline MAE inclusion & Carcass yield (\%) & Breast (\%) & $\operatorname{Leg}(\%)$ & Thigh (\%) & Back (\%) & Wings (\%) \\
\hline $0 \%$ & 74.54 & 20.97 & 11.72 & 10.49 & 20.03 & 7.67 \\
\hline $0.5 \%$ & 75.03 & 22.25 & 10.10 & 10.56 & 17.42 & 7.19 \\
\hline $1.0 \%$ & 74.83 & 22.12 & 10.26 & 10.53 & 17.07 & 7.41 \\
\hline $2.0 \%$ & 74.92 & 22.06 & 9.98 & 10.87 & 17.50 & 7.12 \\
\hline Regression & ns & ns & ns & ns & ns & ns \\
\hline CV $(\%)$ & 5.72 & 6.69 & 12.43 & 5.75 & 7.92 & 8.09 \\
\hline MAE inclusion & Heart (\%) & $\operatorname{Liver}^{1}(\%)$ & Proventriculus (\%) & Gizzard (\%) & \multicolumn{2}{|c|}{ Small intestine (\%) } \\
\hline $0 \%$ & 0.55 & 2.57 & 0.46 & 2.46 & \multicolumn{2}{|c|}{6.04} \\
\hline $0.5 \%$ & 0.56 & 2.56 & 0.43 & 2.12 & \multicolumn{2}{|c|}{5.51} \\
\hline $1.0 \%$ & 0.59 & 2.86 & 0.52 & 2.26 & \multicolumn{2}{|c|}{5.83} \\
\hline $2.0 \%$ & 0.55 & 2.88 & 0.48 & 2.20 & \multicolumn{2}{|c|}{5.60} \\
\hline Regression & ns & L & ns & ns & \multicolumn{2}{|c|}{ ns } \\
\hline CV (\%) & 17.30 & 11.69 & 17.87 & 10.25 & \multicolumn{2}{|c|}{12.35} \\
\hline
\end{tabular}

ns not significant

${ }^{1} P=0.045 ; Y=2.559+0.178 x ; R 2=0.74$

The relative weights of the heart, proventriculus, gizzard, and small intestine of 35-d-old broilers were not influenced ( $p>0.05$ ) by the treatments (Table 6 ). In contrast, an increase ( $p=0.045)$ was observed in the relative weight of the liver as MAE dietary inclusion levels increased. This result may be explained by an increase in liver metabolic rate due to the higher daily intake of omega-3 fatty acids in MAE-fed birds, which may have caused fat infiltration in the liver, as all lipids are first directed to the liver, and subsequently to the other tissues.

The results obtained for the fatty acid profile of the thigh meat are presented in Table 7, showing differences in the levels of several fatty acids, as well as a linear effect $(p<0.05)$ in total saturated fatty acids ( $\Sigma$ SFA)and of mono-unsaturated fatty acids ( $\Sigma$ MUFA), in addition of a change $(p>0.05)$ in total polyunsaturated fatty acid levels ( $\Sigma$ PUFA).

There was a linear effect $(p<0.05)$ on $C 14: 0$, C16:0 and C18:1 fatty acid levels, and a quadratic effect ( $p<0.05)$ on C 20:1, C 18:2, C18:3, C20:5 and C20:6 fatty acid levels, but no influence $(p>0.05)$ on C18:0, C14:1, C16:1 and C20:4 levels. A linear effect $(p<0.05)$ was observed for the sum of $n-6$ fatty acids and a quadratic effect $(p<0.05)$ on $n-3$ and $n-6 / n-3$ fatty acids. On the other hand, there was no effect ( $p>0.05)$ on the PUFA/SFA ratio. There were marked changes in the levels of eicosapentaenoic acid (C20:5 $n-3)$ and of docosahexaenoic acid (C22:6 n-3) in the thigh meat ( $p=0.035$ and $p=0.008$, respectively), with a quadratic effect on the levels of both fatty acids as MAE dietary inclusion increased.

The omega-6/omega-3 (n-6/n-3) ratio of fatty acids decreased along with the increase in algae, because of the increased presence of DHA, primarily in meat. These results agree with those of with Oliveira et al. (2016), who reported changes in the $n-6 / n-3$ ratio in the meat of broilers supplemented with marine algal sources of EPA and DHA. Also, Yan \& Kim (2013) certificated the improvement of fatty acid composition of broiler 
Petrolli TG, Petrolli OJ, Pereira ASC, Zotti CA, Romani J, Villani R, Leite F, Zanandréa FM

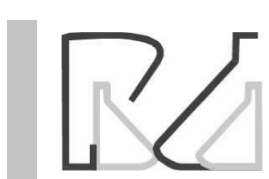

Effects of the Dietary Supplementation with a Microalga Extract on Broiler Performance and FattyAcid Meat Profile

Table 7 - Fatty acid profile of the thigh meat of broilers fed increasing microalga extract levels from 1 to 35 days of age

\begin{tabular}{|c|c|c|c|c|c|c|}
\hline \multirow{2}{*}{ Fatty acid } & \multicolumn{4}{|c|}{ Inclusion levels } & \multirow{2}{*}{ Valor $p$} & \multirow{2}{*}{ Regression } \\
\hline & $0 \%$ & $0.5 \%$ & $1.0 \%$ & $2.0 \%$ & & \\
\hline C14:01 & 0.343 & 0.460 & 0.521 & 0.498 & 0.002 & $\mathrm{~L}$ \\
\hline C 16:02 & 18.582 & 19.466 & 19.902 & 20.288 & 0.009 & $L$ \\
\hline C18:0 & 9.219 & 8.894 & 8.846 & 9.751 & 0.581 & ns \\
\hline$\Sigma$ SFA3 & 28.144 & 28.820 & 28.909 & 30.537 & 0.010 & $\mathrm{~L}$ \\
\hline C14:1 & 0.306 & 0.327 & 0.315 & 0.325 & 0.801 & ns \\
\hline C $16: 1$ & 2.314 & 2.213 & 2.078 & 1.810 & 0.124 & ns \\
\hline C 18:1 n-94 & 24.947 & 23.416 & 21.431 & 19.182 & $<0.001$ & $\mathrm{~L}$ \\
\hline$C 20: 15$ & 0.244 & 0.207 & 0.183 & 0.189 & 0.016 & $\mathrm{Q}$ \\
\hline$\sum$ MUFA6 & 27.812 & 26.164 & 24.007 & 21.507 & $<0.001$ & $\mathrm{~L}$ \\
\hline C $18: 2$ n-67 & 26.766 & 27.427 & 28.517 & 24.385 & 0.010 & Q \\
\hline C18:3 n-38 & 1.917 & 2.050 & 2.251 & 1.610 & 0.034 & Q \\
\hline C20:4 n-6 & 5.573 & 4.538 & 3.313 & 4.019 & 0.700 & ns \\
\hline C20:5 n-39 & 0.861 & 0.756 & 0.684 & 0.939 & 0.035 & Q \\
\hline$C 22: 6 n-310$ & 0.678 & 2.140 & 3.324 & 6.490 & 0.008 & Q \\
\hline$\Sigma$ PUFA & 33.425 & 34.502 & 35.588 & 35.363 & 0.160 & ns \\
\hline$\sum n-611$ & 32.339 & 31.965 & 31.830 & 28.405 & 0.022 & $\mathrm{~L}$ \\
\hline$\sum n-312$ & 2.840 & 4.473 & 5.580 & 8.542 & 0.035 & Q \\
\hline$n-6 / n-313$ & 11.428 & 7.209 & 5.504 & 3.351 & 0.003 & Q \\
\hline PUFA/SFA & 1.193 & 1.161 & 1.170 & 1.196 & 0.826 & ns \\
\hline
\end{tabular}

$1 L^{*}$ Linear effect. $p=0.002 y=0.324+0.052 \times r 2=0.73$

$2 L^{*}$ Linear effect. $p=0.009 y=18.858+0.200 \times r 2=0.87$

$3 L^{*}$ Linear effect. $p=0.010 y=30.141-2.107 \times r 2=0.99$

$4 L^{*}$ Linear effect. $p<0.001 y=24.785+0.725 \times r 2=0.98$

$5 L^{*}$ Quadratic effect. $p=0.016 y=0.245-0.023 x+0.002 \times 2 r 2=0.99$

$6 L^{*}$ Linear effect. $p<0.001 y=28.039-0.708 \times r 2=0.81$

$7 L^{*}$ Quadratic effect. $p=0.010 y=26.559+1.034-0.162 \times 2 r 2=0.94$

$8 L^{*}$ Quadratic effect. $p=0.034 y=1.882+0.813-0.026 \times 2 r 2=0.93$

$9 L^{*}$ Quadratic effect. $p=0.035 y=0.460+0.141 x-0.009 \times 2 r 2=0.47$

$10 Q *$ Quadratic effect. $p=0.008 . y=0.722+2.504 x+0.186 \times 2 r 2=0.99$

$11 L^{*}$ Linear effect. $p<0.022 y=32.874-0.497 x \mathrm{r} 2=0.86$

$12 Q$ * Quadratic effect. $p=0.035 y=2.859+0.805 x-0.012 \times 2 r 2=0.99$

$13 Q^{*}$ Quadratic effect. $p=0.003 y=11.428-3.002 x+0.512 \times 2 r 2=0.99$

meat without compromising growth performance. However, the authors evaluated algae of the Rubrivivax gelatinosus that influences EPA levels, but does not influence the DHA levels. By contrast, Ao et al. (2015), evaluated the addition of $0.0 \%$ to $3.0 \%$ of marine microalgae in the feed of laying hens and found the possibility of egg enrichment with DHA. Hargis \& van Elswyk (1993) pointed out that the omega-3 fatty acid content in chicken meat can be rapidly increased by including marine compounds or rich cereals in the profile of fatty acids in the diet of poultry. Finally, Rymer et al. (2010) observed changes in EPA and DHA levels and in the $n-6 / n-3$ ratio in breast meat and thigh of broilers supplemented with seaweed.

The algae of the genus Schizotrichium is rich in docosahexaenoic acid (C22:6 n-3), and its addition in the diet proved to be efficient in enriching the chicken meat with this fatty acid. The birds have low endogenous production of DHA; however, they have the capacity to deposit DHA the body when present in the diet, without biohydrogenation or prior catabolism in the liver.

\section{CONCLUSION}

The inclusion of seaweed can be used appropriately in the nutrition of broilers. Supplementation of ingredient in bird feed enriches the omega-3 fatty acid content (DHA) in the thigh meat of broilers.

\section{REFERENCES}

Abudabos AM, Okab AB, Aljumaah RS, Samara EM, Abdoun KA, AlHaidary $A A$. nutritional value of green seaweed (Ulva lactuca) for broiler chickens. Italian Journal of Animal Science 2013;12:2, e28

Ao T, Macalintal LM, Paul MA, Pescatore AJ, Cantor AH, Ford MJ, et al. Effects of supplementing microalgae in laying hen diets on productive performance, fatty-acid profile, and oxidative stability of eggs. The Journal of Applied Poultry Research 2015;24(3):394-400. 
Barclay WRK, Meager M, Abril JR. Heterotrophic production of long chain omega-3 fatty acids utilizing algae and algae-like microorganisms. Journal of Applyed Phycology 1994;6:123-129.

Brasil. Ministério da Ciência, Tecnologia e Inovação. Diretrizes para a prática de eutanásia do CONCEA. Brasília: MCTI; 2013.

Carrillo, DS, Casas VMM, Castro GMI, Perez GI, Garcia VR. The use of Macrocystis pyrifera seaweed in broiler diets. Investigation Agraria Production Sanidad Animals 1990;5:137-142.

Cherian G, Gonzales D, Ryu KS, Goeger MP. Long-term feeding of conjugated linoleic acid and fish oil to laying hens: effects on hepatic histopathology, egg quality, and lipid components. Journal of Applied Poultry Research 2007;16:420-428.

El-Deek AA, Asar MA, Safaa-Hamdy MA, Kosba MA, Osman, M. Nutritional value of marine seaweed in broiler diets. Journal of Agricultural Science Mansoura University 1987;12:707-717.

El-Deek AA, Brikaa MA. Nutritional and biological evaluation of marine seaweed as a feedstuff and as a pellet binder in poultry diet. International Journal of Poultry Science 2009;8:875-881.

Ernest R, Warren D. The nutritional value of dehydrated, Blue-Green algae Spirulina platensis for poultry. Poultry Science 1990;69:794-800.

Folch J, Lees M, Sloane-Stanley GH. A simple method for the isolation and purification of lipids from animal tissues. Journal of Biological Chemical 1957;226:497-509.

Gu HY, Liu YG, Shu ZZ. Nutrient composition of marine algae and their feeding on broilers. Chinese Journal of Animal Science 1988;3:12-14.

Hargis PS, Van Elswyk ME. Manipulating the fatty acid composition of poultry meat and eggs for the health conscious consumer. World's Poultry Science Journal 1993;49:251-264.

Herber SM, Van Elswyk ME. Dietary marine algae promotes efficient deposition of $n-3$ fatty acids for the production of enriched shell eggs. Poultry Science 1996;75:1501-1507.

Kramer JKG, Fellner V, Dugan MER, Sauer FD, Mossoba MM, Yurawecz MP. Evaluating acid and base catalysts in the methylation of milk and rumen and rumen fatty acids with special emphasis on conjugated dienes and total trans fatty acids. Lipids 1997;32:1219-1228.

Maroufyan E, Kasim A, Ebrahimi M, Loh TC, Hair-Bejo M, SoleimaniAF. Dietary methionine and $n-6 / n-3$ polyunsaturated fatty acid ratio reduce adverse effects of infectious bursal disease in broilers. Poultry Science 2012;91:2173-2182.

Neijat M, Ojekudo O, House JD. Effect of flaxseed oil and microalgae DHA on the production performance, fatty acids and total lipids of egg yolk and plasma in laying hens. Prostaglandins, Leukotrienes and Essentia Fatty Acids 2016;115:77-88.

Oliveira J, Avanço SV, Garcia-Neto M, Ponsano EHG. Composition of broilers meat. Journal of Applied Poultry Research 2016;25:173-181.

Padhi MK, Raim RB, Chandra P, Senani S, Saha SK, Ahlawat SPS. Effect of feeding sea weeds on performance of Nicobari layer. Animal Science $2003 ; 73: 948-949$

R Core Team. R: A language and environment for statistical computing. Viena: R Foundation for Statistical Computing; 2014.

Ross E, Dominy W. The nutritional value of dehydrated, blue-green algae (Spirulina platensis) for poultry. Poultry Science 1990;69:794-800.

Rostagno HS, Albino LFT, Hannas MI, Donzele JL, Sakomura NK, Perazzo FG, et al. Tabelas brasileiras para aves e suínos: composição de alimentos e exigências nutricionais. $4^{a}$ ed. Viçosa: Departamento de Zootecnia, Universidade Federal de Viçosa; 2017.

Rymer C, Gibbs RA, Givens DI. Comparison of algal and fish sources on the oxidative stability of poultry meat and its enrichment with omega-3 polyunsaturated fatty acids. Poultry Science 2010;89:150-159.

Shunthwal J, Sheoran N. Influence of linseed oil feeding on performance and fatty acid composition of muscles in broiler chicks. The Pharma Innovation Jornal 2017;6(11):268-273.

Tenório AG. Avaliação de desempenho, morfometria intestinal e qualidade de carne de frangos de corte alimentados com dietas suplementadas com extrato de algas [dissertation]. Dois Vizinhos (PR): Universidade Tecnológica Federal do Paraná; 2015.

Toyomizu M, Sato K, Taroda H, Kato T, Akiva Y. Effects of dietary Spirulina on meat color in muscle of broiler chickens. British Poultry Science 2001;42:197-202

Venkataraman, LV, Somasekaran T, Becker, EW. Replacement value of bluegreen alga (Spirulina platensis) for fishmeal and a vitamin-mineral premix for broiler chicks. British Poultry Science 1994;35(3):373-81.

Ventura MR, Castaòon JIR, Mcnab JM. Nutritional value of seaweed (Ulva rigida) for poultry. Animal Feed Science and Technology 1994;49(12):87-92.

Yan L, Kim IH. Effects of dietary $\omega-3$ fatty acid-enriched microalgae supplementation on growth performance, blood profiles, meat quality, and fatty acid composition of meat in broilers. Journal of Applied Animal Research 2013:41(4):392-397.

Zeller S, Barclay W, Abril R, Shahidi F, Finley J. Production of docosahexaenoic acid from microalgae Omega-3 fatty acids: chemistry nutrition and health effects. Washington: American Chemical Society; 2001. p.108124 
